\title{
TAOK3 wt Allele
}

National Cancer Institute

\section{Source}

National Cancer Institute. TAOK3 wt Allele. NCI Thesaurus. Code C106219.

Human TAOK3 wild-type allele is located within $12 q$ and is approximately $223 \mathrm{~kb}$ in length.

This allele, which encodes serine/threonine-protein kinase TAO3 protein, plays a role in both signal transduction and serine/threonine phosphorylation. 